\title{
THE EFFECT OF FLUCONAZOLE AND AMPHOTERICIN B ON MACROPHAGE FUNCTIONS
}

\author{
Glazar Irena, ${ }^{1}$ Pezelj-Ribaric Sonja, ${ }^{1}$ Abram Maja ${ }^{2}$ \\ ${ }^{1}$ Department of Oral Medicine, Dental Clinic, University Hospital Rijeka, Croatia \\ ${ }^{2}$ Department of Microbiology, University Hospital Rijeka, Croatia
}

Primljen/Received 31. 08. 2015. god.

Abstract: Background: Different antimicrobial drugs inhibit functions of the microbial cells but, unfortunately, some of these drugs can also affect the host cells, including macrophages. Since these cells represent the baseline defense against microbial agents, it is important that they are fully activated.

Materials and Methods: In the present study we investigated the effect of amphotericin B and fluconazole on the functions of peritoneal macrophages from $\mathrm{Balb} / \mathrm{c}$ mice treated with these antimycotics. For each antimycotic the therapeutic dose used in clinical practice (calculated on the mouse body weight) and two-fold higher doses were administered intraperitoneally once a day for three consecutive days. The control group was treated with saline in the same way. Four different tests, candidacidal assay, nitroblue tetrazolium test, adherence capability and phagocytic capability, were used to determine macrophage functions.

Results: Our results confirmed positive effect of high dose amphotericin B on phagocytic capability $(31.00 \pm 4.46 \%)$, metabolic changes $(27.93 \pm 6.63 \%)$ and adherence capacity $(59.24 \pm 8.67 \%)$. Lower doses of drug amphotericin B $(2 \mathrm{mg} / \mathrm{kg})$ significantly increased the adherence index of macrophages (71.99 \pm $5.55 \%$ ) and intensity of the NBT intracellular reduction $(30.20 \pm 3.83 \%)$. Maximum dose of fluconazole expressed significantly higher phagocytic index (30.77 $\pm 2.17 \%)$, metabolic changes $(24.00 \pm 4.07 \%)$ and candidacidal activities $(27.73 \pm 6.73 \%)$, while lower doses of fluconazole $(15 \mathrm{mg} / \mathrm{kg})$ significantly increased the adherence index of macrophages $(75.58 \pm 5.47 \%)$ as well as the phagocytic index $(29.23 \pm 2.40 \%)$. Other results were similar as in control group.

Conclusion: Positive immunomodulatory effects of fluconazole and amphotericin B may be clinically relevant especially in compromised patients who are predisposed to opportunistic fungal infections and re-
Prihvaćen/Accepted 24. 10. 2015. god.

quire a long-term antimycotic therapy. Synergistic action of macrophages and antimycotics can influence the course of disorders related to immune suppression.

Key words: Amphotericin B, fluconazole, macrophage functions.

\section{INTRODUCTION}

Fungal infections pose a growing medical problem because of the markedly increased numbers of immunologically compromised patients due to human immunodeficiency virus, cancer chemotherapy, bone marrow transplantation or other debilitating conditions $(1,2)$. These infections are commonly associated with significant morbidity and mortality. Many of these infections are caused by, in normal conditions, harmless fungi. The most common infection associated with this group of patients is candidiasis (3-5). Resistance to fungal infections is based on cell-mediated immunity. Macrophages play a key role in the host immune system. They act as a barrier against microbial invasion and dissemination. Their ability to be mobilized into infectious sites from bone marrow and blood, as well as their competence for phagocytosis and killing of microorganisms is often decisive in determining the outcome of infection $(1,6-8)$. Once activated, they act directly by destroying bacteria, parasites, viruses, fungi and tumor cells with reactive oxidants and hydrolytic enzymes, or indirectly by releasing specific mediators such as interleukin-1, tumor necrosis factor-alpha and others which can regulate other cells' activities. They are also responsible for processing the antigens and presenting the digested peptides to lymphocytes, while playing the leading role in damage repair (9-11). However, chemotherapeutic agents, corticosteroids, and radiation, disrupt these defense mechanisms. If patients are to survive infections associated with neutropenia 
and other compromises in host defense due to use of these therapies, it is important to reverse or at least lessen immunosuppresion in this patients $(2,4)$.

Fungal infections are treated with antifungal drugs. Antifungal agents which are available for treatment of these infections are the polyenes, the azoles and the echinocandins (12-14). Polyene antifungal drug amphotericin B is a standard therapy for invasive Candida infections, but high frequency of renal toxicity limits its use. Recently, newer lipid formulations of amphotericin B with less adverse effects and activities similar to that of standard amphotericin B have become available (15). The triazole fluconazole is a leading drug to prevent and to treat candidal infections. This drug displays predictable pharmacokinetics and an excellent tolerance profile in all groups of patients (12-14, 16).

Different antimicrobial drugs inhibit functions of the microbial cells but, unfortunately, some of these drugs can also affect the host cells, including macrophages. Since these cells represent the baseline of defense against microbial agents, it is important that these cells are fully activated $(14,15)$.

The aim of this study was to investigate the effect of amphotericin B and fluconazole on macrophage functions (adherence, phagocytosis, intracellular killing and digestion of the drug) on experimental mouse model.

\section{MATERIALS AND METHODS}

Animals. Female BALB/c mice, 9 weeks old (obtained from the Medical Faculty, University of Rijeka) were used in this study. They were randomly divided in five groups each containing five animal. The animals were kept in plastic cages and were given standard laboratory rodent food and water ad libidum. The Ethical Committee of the Medical Faculty University of Rijeka approved the study and all procedures using mice.

Antimycotics. Two antifungal drugs Amphotericin-B (Amphotericin-B, Bristol-Myers Squibb, Woerden, The Netherlands) and fluconazole (Diflucan, Pfizer, Ambroise, France) were tested.

For each antimycotic, the therapeutic dose used in clinical practice (calculated on the mouse body weight) and twofold higher dose were administrated intraperitoneally once a day, for three consecutive days. Standard preparation of amphotericin B was given in doses of $2 \mathrm{mg} / \mathrm{kg} /$ day and $4 \mathrm{mg} / \mathrm{kg} /$ day while fluconazole was administrated in doses of 15 and $30 \mathrm{mg} / \mathrm{kg} /$ day. Control group was treated with saline $(0,85 \% \mathrm{NaCl})$ in the same way.

Peritoneal macrophages. $24 \mathrm{~h}$ after receiving the last dose of the antimycotic, the animals were sacrificed by cervical dislocation. Peritoneal macrophages were obtained after the peritoneal cavity was washed with $4 \mathrm{ml}$ of RPMI medium (Institute of Immunology, Zagreb, Croatia). The injected medium containing peritoneal cells was slowly aspirated. Quantitative analysis of the cell suspension was performed immediately after collection in a Neubauer chamber.

Macrophage adherence assay. Two plastic test tubes $(16 \times 160 \mathrm{~mm})$ were filled with $0.2 \mathrm{ml}$ of the same cell suspension. The tubes were incubated for 2 hours in a horizontal position at $37^{\circ} \mathrm{C}$ in a humidified atmosphere. After gentle removal, the number of nonadherent macrophages was counted in a Neubauer chamber. The results were expressed as the adherence index (AI).

Phagocytic assay. Two plastic rings, $2 \mathrm{~mm}$ high and $16 \mathrm{~mm}$ in diameter, were stuck with paraffin onto microscopic slides. The wells were filled with the cell suspension containing peritoneal macrophages in RPMI medium and heat killed Candida albicans. The wells were covered with cover slips and incubated at $37^{\circ} \mathrm{C}$ for 30 minutes in a humid atmosphere. After incubation the cover slips were removed and the liquid was decanted. The plastic rings were removed and the slides were dried, stained with Wright's stain and examined with immersion. The total number of macrophages and the percentage of ingested Candida albicans were counted. More than 100 cells per each well were counted. The results were expressed as phagocytic index (PI).

Candidacidal assay. Plastic tubes were filled with $0.1 \mathrm{ml}$ of cell suspension and $0.005 \mathrm{ml}$ suspension of viable Candida albicans. The tubes were then incubated at $37^{\circ} \mathrm{C}$ for one hour in a humid atmosphere. After incubation, the suspension was treated with cold distilled water for 15 minutes to cause cells lysis. Light microscopic examination showed blue killed Candida while the alive ones remained were colorless. Free Candida albicans was colored with Tripan blue. More than 300 Candida were counted and the results were expressed as percentage of killed Candida albicans at 100 microorganisms.

Nitroblue tetrazolium (NBT)-dye assay. NBT-assay expresses metabolic changes in the macrophages after phagocytosis foreign particles. Metabolic changes include reduction of the colorless NBT in the cytoplasm of macrophages in black color formasan. Plastic tubes were filled with $200 \mu \mathrm{l}$ of the cell suspension and $200 \mu \mathrm{l}$ of the nitroblue tetrazolium. The tubes were then incubated at $35 \mathrm{E} \mathrm{C}$ for 15 minutes in a humid atmosphere and for 15 minutes at room temperature. The suspension was then placed on microscopic slides and dried. Immediately after, dried slides were stained with Wright's stain and examined with immersion. The total number of macrophages and the percentage of formasan positive cells with blue or black inclusions were determined. More than 100 cells per slides were coun- 
ted. Results were expressed as percentage of NBT positive cells.

Comparison between groups was performed by Student t-test. Results are expressed as mean and standard deviation. The level of significance was set at 0.05 .

All animal experiments were carried out in accordance with Policies and Guidelines for the Care and Use Laboratory Animals. All effort was made to minimize animal suffering.

\section{RESULTS}

\section{The effect of fluconazole on macrophage functions}

Our results showed that lower dose of fluconazole $(15 \mathrm{mg} / \mathrm{kg})$ significantly increased the adherence index of macrophages $(75.58 \pm 5.47 \%)$ as well as the phagocytic index $(29.23 \pm 2.40 \%)$, but did not demonstrate any major alteration in C. albicans killing assay and NBT intracellular reduction.

Macrophages treated with maximum dose (30 $\mathrm{mg} / \mathrm{kg}$ ) of fluconazole had significantly higher phagocytic index $(30.77 \pm 2.17 \%)$, metabolic changes $(24.00 \pm 4.07 \%)$ and candidacidal activities $(27.73 \pm$ $6.73 \%$ ) comparing to control group ( $\leq 0.05)$.

\section{The effect of amphotericin B on macrophage functions}

Lower doses of drug amphotericin B (2 mg/kg) significantly increased the adherence index of macrophages $(71.99 \pm 5.55 \%)$ and intensity of the NBT intracellular reduction $(30.20 \pm 3.83 \%)$, while other results were similar to the control group.

Treatment of macrophages with higher dose of amphotericin B (4 mg/kg) showed that phagocytic capability $(31.00 \pm 4.46 \%)$, metabolic changes $(27.93 \pm$ $6.63 \%)$ and adherence capacity $(59.24 \pm 8.67 \%)$ were increased significantly.

Results are summarized in Table 1.

\section{DISCUSION}

The host response to fungal infections requires co-actions of immune system and antifungal drugs to effectively clear the microorganisms. Antifungal drugs may have broad immunomodulatory properties. Cytokines, effector cells, and antifungals appear to work synergistically to oppose fungal growth. Positive immunomodulatory effects of antifungal drugs may be clinically relevant, especially in compromised patients who are predisposed to opportunistic fungal infections and require a long-term antimycotic therapy (17).

In this study, the most commonly used antifungal drugs were studied for their impact on different macrophage functions. Several studies examined the influence of fluconazole on macrophage activity against Candida. It appears that the presence of macrophages provides synergistic activity with fluconazole against Candida isolates (14). Garcha presented the data that indicate that the combination of two fungistatic agents, fluconazole and macrophages, can synergize for significant anticandidal activity, especially against fluconazole-susceptible isolates (18). In contrast, investigation presented by Yamaguchi et al. suggested that fluconazole had no immunological effect (19). Results of our investigation confirmed synergic activity of as a stimulant on phagocytosis, oxidative burst and microbicidal activity using both fluconazole and macrophages in immune response. We found that fluconazole acted maximum dose and lower dose of fluconazole, although better results were obtained with maximum dose. Fidan and his co-workers concluded in their research that fluconazole has an immunomodulatory effect connected with the presence of different cytokines (17).

It is well known that Amphotericin B has an immunostimulatory effect to macrophages and enhances their function $(17,19)$. It also has a stimulatory effect on macrophages to produce cytokine tumor necrosis factor alpha (TNF- $\alpha$ ) which may be responsible for the immunomodulatory effects of Amphotericin B (20).

Table 1. Adherence index, Phagocytic index, NBT-dye assay and Candidacidal assay for amphotericin $B$ and fluconazole

\begin{tabular}{|l|c|c|c|c|}
\hline & $\begin{array}{c}\text { Adherence } \\
\text { index (AI) }\end{array}$ & $\begin{array}{c}\text { Phagocytic } \\
\text { index (PI) }\end{array}$ & $\begin{array}{c}\text { NBT-dye assay } \\
(\%)\end{array}$ & $\begin{array}{c}\text { Candidacidal } \\
\text { assay (\%) }\end{array}$ \\
\hline Control & $62.21 \pm 14.26$ & $22.95 \pm 3.55$ & $20.93 \pm 1.71$ & $14.10 \pm 623$ \\
\hline Fluconazole $(15 \mathrm{mg} / \mathrm{kg} /$ day $)$ & $75.58 \pm 5.47^{*}$ & $29.23 \pm 2.40^{*}$ & $19.20 \pm 3.52$ & $11.40 \pm 4.40$ \\
\hline Fluconazole $(30 \mathrm{mg} / \mathrm{kg} /$ day $)$ & $68.84 \pm 8.68$ & $30.77 \pm 2.17^{*}$ & $24.00 \pm 4.07^{*}$ & $27.73 \pm 6.73^{*}$ \\
\hline AmphotericinB $(2 \mathrm{mg} / \mathrm{kg} /$ day) & $71.99 \pm 5.55^{*}$ & $22.67 \pm 3.32$ & $30.20 \pm 3.83^{*}$ & $11.13 \pm 4.51$ \\
\hline AmphotericinB $(4 \mathrm{mg} / \mathrm{kg} /$ day) & $59.24 \pm 8.67^{*}$ & $31.00 \pm 4.46^{*}$ & $27.93 \pm 6.63^{*}$ & $12.60 \pm 4.65$ \\
\hline
\end{tabular}

Values are expressed as mean $\pm \mathrm{SD}$ from each group. Student t-test was used to compare data among the groups.

* Significant increased functions comparing to control group at level $\mathrm{p}<0.05$. 
We confirmed that both doses of amphotericin B had effect on macrophages, increasing significantly their phagocytic ability and oxidative burst. Our results are also in correlation with the results obtained by Yamaguchi who concluded that amphotericin B has a profound effect on macrophages in vitro and in vivo, and that this action is mediated by cytokines (19).

Antifungals used to treat infections, especially in immunocompromised patients, could have a potent antimicrobial effect to fungi and positive impact on host defense mechanisms such as macrophage functions.

\section{CONCLUSION}

It is preferable that drugs used have a slightly stimulatory, rather than an immunosuppressive effect on the cells of the immune system. Since some drugs can suppress macrophage functions, it would be appropriate to determine susceptibility of microorganisms to a certain drug since even minor immunosuppressive effect can additionally complicate the course of the disease. Recent investigation suggested that macrophage functions are connected with activation of different cytokines but further studies should be carried out in order to understand better the mechanism by which target host cells react in response to immunomodulators.
Abbreviations:
AI - adherence index
NBT assay - Nitroblue tetrazolium dye assay
TNF- $\alpha$ - tumor necrosis factor alpha

\title{
Sažetak
}

\section{UČINAK FLUKONAZOLA I AMFOTERICINA B NA FUNKCIJE MAKROFAGA}

\author{
Glažar Irena, ${ }^{1}$ Pezelj-Ribarić Sonja, ${ }^{1}$ Abram Maja ${ }^{2}$ \\ ${ }^{1}$ Department of Oral Medicine, Dental Clinic, University Hospital Rijeka, Croatia \\ ${ }^{2}$ Department of Microbiology, University Hospital Rijeka, Croatia
}

Uvod: Različiti antimikrobni lekovi inhibiraju funkcije mikroorganizama, nažalost deluju i na ćelije domaćina, uključujući i makrofage. Obzirom da su makrofazi bazna linija odbrane organizma, potrebno je da budu u potpunosti aktivirani.

Materijali i metode: $U$ istraživaanju ispitivan je učinak flukonazola i amfotericina $\mathrm{B}$ na funkcije peritonealinih makrofaga Balb/c miševa. Za svaki antimikrobni lek korišćena je terapeutska doza i dvostruko veća doza. Miševi su tretirani uzastopno tri dana. Kontrolna grupa miševa tretirana je s fiziološkim rastvorom identičnim postupkom. Da bi se odredila funkicija makrofaga korišćena su četiri testa: kandidacidni test, nitroblutetrazolijski test, sposobnost adherencije i fagocitna sposobnost.

Rezultati: rezultati su potvrdili pozitivan učinak amfotericina B na fagocitozu $(31.00 \pm 4.46 \%)$, metaboličke promene $(27.93 \pm 6.63 \%)$ i sposobnost adhe-

\section{REFERENCES}

1. Dineshshankar J, Sivakumar M, Karthikeyan M, Udayakumar P, Shanmugam KT, Kesavan G.. Immunology of oral candidiasis. J Pharm Bioallied Sci. 2014;6 (suppl 1): 9-12.

2. Loo DS. Systemic antifungal agents: an update of established and new therapies. Adv Dermatol. 2006; 22:101-24.

3. Tuzun Y, Kalayciyan A, Engin B, Tüzün B. Life-threathing disorders of mucous membranes. Clinics Dermat. 2005; 23(3): 267-75. rencije $(59.24 \pm 8.67 \%)$. Niža doza amfotericina B (2 $\mathrm{mg} / \mathrm{kg}$ ) značajno povećava indeks adherencije makrofaga $(71.99 \pm 5.55 \%)$ i metaboličke funkcije $(30.20 \pm$ $3.83 \%$ ). Viša doza flukonazola značajno povećava fagocitni indeks $(30.77 \pm 2.17 \%)$, metaboličke aktivnosti $(24.00 \pm 4.07 \%)$ i kandidacidne aktivnosti $(27.73 \pm$ $6.73 \%)$, dok niža doza flukonazola $(15 \mathrm{mg} / \mathrm{kg}$ ) značajno povećava indeks adherencije $(75.58 \pm 5.47 \%)$ i fagocotni indeks $(29.23 \pm 2.40 \%)$. Rezultati su sličnii u kontrolnoj grupi.

Zaključak: Pozitivan imunomodulatorni učinak flukonazola i amfotericina B može biti klinički značajan kod imunološki kompromitovanih bolesnika kod kojih postoji predispozicija razvoja oportunističkih gljivičnih infekcija. Sinergističan učinak makrofaga i antimikotika može uticati na razvoj i tok bolesti.

Ključne reči: Amfotericin $\mathrm{B}$, fluconazol, makrofagne funkcije.

4. Perfect JR, Hachem R, Wingard JR. Update on epidemiology of and preventive strategies for invasive fungal infections in cancer patients. Clin Infect Dis. 2014; 59 (suppl 5): 352-5.

5. Sims CR, Ostrosky-Zeinchenr L, Rex JH: Invasive candidiasis in immunocompromised hospitalized patients. Arch Med Res. 2005; 36(6): 660-71.

6. Ahmad I, Owais M, Shahid M et al. Combating fungal infections, Problems and remedy. 1 st ed. Springer, 2010.

7. Glocker E, Grimbacher B. Chronic mucocutaneous candidiasis and congenital susceptibility to Candida. Curr Opin Allergy Clin Immunol. 2010; 10(6): 542-50. 
8. Fidel PL Jr: Immunity to Candida. Oral Dis. 2002; 8 (suppl 2): 69-75.

9. Hume DA: The mononuclear phagocyte system. Curr Opin Immunolog. 2006; 18(1): 49-53.

10. Lionakis MS. New insights into innate immune control of systemic candidiasis. Med Mycol. 2014; 52(6): 555-64.

11. Kitahara N, Morisaka H, Aoki W et al. Description of the interaction between Candida albicans and macrophages by mixed and quantitative proteome analysis without isolation. AMB Express. 2015; 5(1): 127.

12. Miyazaki TI, Kohno S. Current recommendations and importance of antifungal stewardship for the management of invasive candidiasis. Expert Rev Anti Infect Ther. 2015; 13(9): 1171-83.

13. Musiol R, Mrozek-Wilczkiewicz A, Polanski J. Synergy against fungal pathogens: Working together is better than working alon. Curr Med Chem. 2014; 21(7): 870-93.

14. DiDomenico B: Novel antifungal drugs. Curr Opin Microbiol. 1999; 2(5): 509-15.

Correspondence to /Autor za korespondenciju

Irena Glažar, PhD, DMD

Department of Oral Medicine

Dental Clinic, University Hospital Rijeka, Croatia

Krešimirova 40,

Rijeka HR-51000, Croatia,

Tel: ++38551345634;

Fax: ++38551345630;

Emal: irena.glazar@medri.uniri.hr
15. Varlam DE, Siddiq MM, Parton LA, Rüssmann H. Apoptosis contributes to amphotericin B-induced nephrotoxicity. Antimicrob Agents Chemother. 2001; 45(3): 679-85.

16. Yu S, Chai X, Wang Y, et al. Triazole derivatives with improved in vitro antifungal activity over azole drugs. Drug Des Devel Ther. 2014; 8: 383-90.

17. Dodds ES, Drew RH, Perfect JR: Antifungal Pharmacodynamics: Review of the Literature and Clinical Applications. Pharmacotherapy. 2000; 20(11): 1335-55.

18. Garcha UK, Brummer E, Stevens DA. Synergy of fluconazole with macrophages for antifungal activity against Candida albicans. Mycopathologia 1995-1996; 132(3): 123-8.

19. Yamaguchi H, Abe S, Tokuda Y. Immunomodulating activity of antifungal drugs. Ann N Y Acad Sci. 1993; 685: $447-57$.

20. Mesa-Arango AC, Scorzoni L, Zaragoza O. It only takes one to do many jobs: Amphotericin $\mathrm{B}$ as antifungal and immunomodulatory drug. Front Microbiol. 2012; 3:286. eCollection 2012. 